\title{
The Adversarial Proceedings Principle in the Civil Process
}

\section{Luan Hasneziri}

PhD External Lecturer at Albanian University and at the Faculty of Laë of the University of Tirana

\section{Abstract}

One of the most important principles of civil process is the adversarial proceedings principle. This principle characterizes the civil process from its beginning in the trial in the court of first instance, in the court of appeal, until its conclusion in the High Court. Moreover, with the new changes that have been made in the civil procedural law, this principle finds application even before the beginning of the trial in the first instance. According to these changes, the party against whom the lawsuit is filed, before the trial against this party begins, has the right to present its claims against the lawsuit, in a document called "Declaration of defence", leaving enough time for the fulfillment of this right for a period of 30 days. This scientific work will consist of tëo main issues. The first issue will address the meaning and importance of the adversarial proceedings principle in the civil process. In this issue, two different systems will be analyzed in the application of this principle, analyzing the advantages and disadvantages of each of them. The second issue will analyze the elements of the adversarial proceedings principle, looking at these elements in practical terms and the consequences that their nonimplementation may bring. In this scientific work, the adversarial proceedings principle will be seen as part of the fair legal process provided by the Constitution of Albania and analyzed in several decisions of the Constitutional Court of Albania. This principle will also be addressed in the framework of international law, focusing on the way in which this principle is expressed in Article 6 of the European Convention on Human Rights and in the decisions of the Strasbourg Court regarding the fair legal process. At the end this scientific work will be given its conclusions, as well as the bibliography where this work is based.

Keywords: state of law, equality of parties in the process, the adversarial proceedings principle, the right of private defence, the right to a fair trial 


\section{Introduction}

\section{The meaning and importance of the adversarial proceedings principle in the civil process.}

This principle is one of the basic principles of the civil judicial process, which, based on its importance is also provided in the Constitution of the Republic of Albania. A special provision of the Constitution expressly provides that everyone has the right to be heard before being judged by the court. From the interpretation of this constitutional provision, it results that it defines the right of every person to be informed about the trial that is taking place against him. The recognition of this right is made in order for him to present his claims in the case, before the court decides, in relation to the case in question. ${ }^{1}$.

In accordance with this principle of the Constitution, the Code of Civil Procedure, in some articles, has defined this very important principle of civil judicial process. According to the provisions of this Code, the parties have the right to be notified of the trial that is taking place against them, and no party can be judged without being heard or summoned to trial. ${ }^{2}$. It is important to note that the participation of the respondent in the trial is a right and not an obligation. This means that the party against whom the trial is conducted is not obliged to participate in the trial, except in cases when the law expressly provides for the appearance of the party before the court.

The adversarial proceedings principle in the civil process is one of the oldest principles of civil law, known in Roman law as the term: "Audiatur et altera pars", can also be translated as the principle of equality of arms in the process ${ }^{3}$. Hearing the party before being judged by the court is the basic precondition for applying the principle of adversarial proceedings. Of course, if the opportunity to be heard is not given to $\mathrm{n}$ the party, we can not have an application of this principle and in this way we would be dealing with a violation of the fair legal process.

The right of a party to be heard before a trial is not an absolute and unrestricted right, which means that the party must be legally and in accordance with the rules of civil procedure, the right to be heard before being judged. In cases where the party has been duly recognized the right to be heard before the trial, being regularly informed of the day and hour of the trial and this party has not appeared in court, without reasonable cause, this does not deprive the court to resolve the dispute even without hearing the party.

\footnotetext{
${ }^{1}$ Article 33/1 of the Constitution provides: "1. Everyone has the right to be heard before being judged by the court".

${ }^{2}$ Article 18 of the Code of Civil Procedure stipulates: "No party may be judge without being heard or summoned to trial.".

3 See also: Kola, Tafaj, F; Vokshi; "Civil Procedure", Part I, Edition II, printed by the Publishing House

"Albas", Tirana 2018, page 32.
} 
This position of the respondent party, by not appearing in court, despite the regular notice, constitutes in itself the principle of availability of the party, which may come to the hearing and be heard, or may not appear and present or may not present evidence. The adjudication of the case even without the appearance of the party, without reasonable reasons, in cases when the party has been duly notified, does not constitute a violation of the principle of adversarial principle, but is in full compliance with this principle.

This also results from the constitutional provisions which stipulate that the right to be heard before being judged does not benefit the person who evade justice. ${ }^{1}$ Even the Code of Civil Procedure issued in this conclusion, as it states that no party can be judged without being heard or without being summoned to trial, which means that for the application of the adversarial proceedings principle summoning of the party is sufficient. The application of the principle of adversarial proceedings is related to another important principle of the civil process which is the "equality of arms" in the process according to this principle, the parties in the civil process should be given an equal opportunity to defend themselves, to present evidence and to oppose the evidence presented by the other party. Failure to implement the principle of equality of arms in the process, constitutes a violation of the right to a fair legal process, provided by Article 42 of the Constitution of Albania and Article 6, point 1 of the European Convention on Human Rights, a fact established also in some decisions of the Constitutional Court of Albania and the Strasbourg Court.

Seen from a historical point of view, the principle of adversarial proceedings has been applied in court proceedings since ancient times, finding a very large application, especially in Roman law. The above principle was not applied in the medieval period and was reborn in the state of liberal democracy, in these last two centuries and to continue to be applied today, in almost all civil processes of modern states, regardless of the system of law.

Also, starting from the rights that the parties have in the process, but especially the role that the court has in it, based on the application of the principle of adversarial proceedings, the civil judicial process can be investigative or contradictory ${ }^{2}$. The civil investigative trial has the following characteristics:

a) The court in the civil investigative judicial process has an active role in the development of this process. It is the most important part of the process and all parties are at its service, to present any evidence and act that the court deems important;

\footnotetext{
${ }^{1}$ Article $33 / 2$ of the Constitution provides: " 2 . This right (meaning, to be heard before trial, underlining of the author) cannot benefit the person evade from justice".

2 Lamani, Alqiviadh, "Civil Procedure", Tirana: 1961, page 24.
} 
b) All evidence in the civil investigative judicial process taken from the court and the parties are obliged to bring only that evidence that the court deems necessary for the resolution of the case;

c) The parties are not subjects of the civil judicial process, but the "object" of this process and they do not participate in the judicial investigation of the case, which is the sole competence of the court;

c) The court has the right to take the evidence, and is the only subject who has such a right, while the parties do not have the right to present evidence which has not been taken by the court, but serve as a source for taking evidence by the court. In contrast to the investigative system of civil litigation, the adversarial civil process has the following characteristics:

a) The court has a passive role in the adversarial civil trial. This means that the court stands on the parties, and has an arbitrator role, in the civil litigation, resolving the case based on the evidence presented by the parties. The parties and not the court are the main part of the civil litigation, they are free to present any evidence, which are related to the case and they deem useful, in their favour, while the court is limited only to the evaluation of evidence and in the fair resolution of the case on the basis of the evidence and facts examined; b) Evidence in adversarial civil litigation is not collected by the court, but is presented by the parties, who are free to present any evidence they deem necessary to prove the facts alleged by them. The role of the court in this case is limited to making a decision to allow the examination of the evidence requested by the parties. The court in this decision allows to examine only those evidences, which are related to the case and are necessary for the examination of the facts claimed by the parties. For the evidence which are not related to the case, or which the court deems that are not necessary to prove the facts claimed by the parties, the court in this case with a decision decides not to allow their examination;

c) Not only the court, but also the parties are subjects of the civil judicial process in the adversarial trial and are the parties who conduct the judicial investigation of the case, presenting evidence and legal claims, while the court as a subject of civil proceedings, and has as its sole duty to direct this judicial inquiry and at its end to settle the dispute;

c) The court has no right to take evidence in adversarial civil litigation, but only the parties have the right to present evidence. They are the only subject who presents evidence in this civil litigation and the court should decide only on the basis of the evidence presented by the parties which should have full and equal capacity to act in this process $^{1}$.

${ }^{1}$ See also: Article1 of Civil Code of the Republic of Albania. 
Our Code of Civil Procedure has accepted as a type of judicial process, the adversarial process, therefore, we will focus more specifically on the clarification of this type of judicial process, which has as its main feature the fact that it is based on the adversarial proceedings principle. This principle requires that the civil litigation be conducted in a contradictory manner, which means that the party filing the lawsuit is obliged to present before the court the facts on which he bases his research, as well as the evidence that serves to prove these facts. On the other hand, the party against whom the lawsuit is filed has the right to file claims to oppose the facts raised in the lawsuit, as well as to present the evidence on which he bases his claims.

Despite the fact that in a state of law where the principle of independence and impartiality of the court is applied and where the court stands as arbitrator over the parties in the process, the most acceptable system of civil proceedings is that of adversarial proceedings, we can say that each of these two systems has its advantages and disadvantages. Thus one of the most important disadvantages of the civil investigative process is the fact that the court having an active role in the process, collecting the evidence itself and administering the process, thus it expresses its bias in relation to resolving the case, not fulfilling the criteria of being an impartial court. By acting in this way, the entire trial conducted according to the civil investigative process, risks to violate the principle of a fair legal process, turning the trial into an irregular trial and thus violating the Article 42 of the Constitution of Albania and Article 6, point 1 of the European Convention on Human Rights.

On the other hand, the civil investigation process can be considered as having the advantage that the court is free and has all the possibilities to conduct a full and comprehensive investigation of the case, without being limited to the requests of the parties. This advantage of this process, if it's carefully considered by the court, will make it possible for the issue to be resolved in a complete and fair manner, but the court must in any case be careful that the actions carried out by her in the process, must be impartial and equal to both parties in the process.

The adversarial civil process has a number of advantages over the civil investigative process, as it guarantees the impartiality of the court in the process, as well as it gives the parties the opportunity to administer and control the process. In this process, the court is an arbitrator and stands on the parties, and bases its decision only on the basis of the evidence presented by the parties, not having the right to take evidence itself or to conduct a judicial investigation on its own initiative or mainly. 
Although the adversarial civil process has many advantages, it can be said that this type of process has as a disadvantage the fact that the court, not having the right to take evidence mainly and not to conduct a judicial investigation on its own initiative, risks not having a full and comprehensive investigation of the case, which constitutes an obligation for the court, the non-implementation of which also leads to a violation of the right to a fair legal process provided by Article 42 of the Constitution of Albania and Article 6, point 1 of the European Convention on Human Rights. According to the Code of Civil Procedure, the court has the obligation to conduct a regular legal process, by guaranteeing a full and comprehensive investigation of the case according to law ${ }^{1}$.

Closely related to the court's obligation to conduct a full and comprehensive investigation of the case, is also its obligation to enforce the law and to resolve the dispute in accordance with the provisions of applicable law. Also, the court must make an accurate determination of the facts and actions related to the dispute, without being influenced by the claims that the parties may make, however, it cannot change the legal basis of the lawsuit without the request of the party.

In order to properly implement the obligation of the court to implement the law or legislation in force, as well as to make an accurate determination of the facts related to the case, regardless of the claims of the parties, sometimes different and wrong positions have been held in court practice. These issues have been finally resolved with the Unifying Decision of the High Court no. 9, dated 9.3.2006, which has unified the case law in this way: In conclusion, according to the Article 16 of the Code of Civil Procedure, the correct determination of the facts and actions (more precisely the events and actions that constitute legal facts) related to the dispute is made by the court reviewing the case, while the determination of the legal basis of the lawsuit is made by the plaintiff himself upon filing the lawsuit and is in his full disposition to change it until the end of the judicial investigation, making a request to the court in an appropriate procedural form.

The High Court, in this Unifying Decision, on this issue, among others, argues that: “... Contrary to the above reasoning of the Court of Appeals, the Joint Panels of the High Court consider the decision unfounded in procedural law of the appeal, and express the annulment of this decision, as well as leaving in force the decision of the first instance with the completion of its reasoning. It is true that according to Article 16 of the Code of Civil Procedure, it is the obligation of the court to make an accurate determination of the facts and actions related to the dispute, without relating to the determination that may be proposed by the parties. However, the court of appeal did not make an accurate and complete citation of Article 16 of the Code of Civil Procedure, and moreover, and has not correctly interpreted this provision.

\footnotetext{
${ }^{1}$ Article 14 of the Code of Civil Procedure provides: "The court has a duty to conduct a due process of law, by guaranteeing the conduct of a full and comprehensive investigation of the case, in accordance with the law."
} 
... On the other hand, in accordance with the principle of maintaining impartiality in the trial, the court which has concluded in a legal determination of the facts of the case, different from the qualification made to them by the plaintiff, through reference to the relevant provision of law material, has no right to be imposed by intervening and changing the legal basis of the lawsuit determined by the plaintiff. In the civil trial the court does not and cannot have an active role.

Article 185 of the Code of Civil Procedure stipulates the use of the term "legal cause of action", in addition to the term "object of the lawsuit".

The doctrine of civil procedural law has clearly defined these two main elements of a lawsuit. The cause is the reason of the judicial inquiry, which is divided into law and in a state of fact that is against this right (causa pretendi), i.e. that violates, violates or denies the subjective right of the plaintiff. On the other hand, the object is what is required by the lawsuit, i.e. law enforcement and the benefit of what is required and that comes as a result of law enforcement (petitum).

... It is clear that the above constituted the cause and object of the lawsuit, which ended with a final decision in the previous trial. This decision, on the basis of which there may be various claims, can not be subject to any kind of revision in this new trial.... 1 .

\section{Elements of the principle of adversarial principle}

As stated with in the above case, one of the elements of the adversarial principle is the right of a party to be summoned to trial before he is judged. This right of the party to participate in the trial is not absolute and the party who evade justice cannot benefit from this right.

The non-application of this element by the court makes us face an unfair judicial process, thus violating the Article 42 of the Constitution of Albania and Article 6, point 1 of the "European Convention on Human Rights". Another element of the adversarial principle is that the party against whom the lawsuit has been filed has the right to be acquainted with the lawsuit and the acts that accompany it before the case is considered by the court, as well as to be given sufficient time to prepare the defense, giving her the opportunity to present her objections and claims in the "Statement of Defense". According to the changes made in the Code of Civil Procedure, with law no. $38 / 2017$, the court after evaluating the lawsuit without defects, requires the respondent to issue a statement of defense, within 30 days of notification of the lawsuit. The statement of defense as the act by which the defendant presents his claims and evidence, against the lawsuit filed against him, before the main trial begins, must contain:

${ }^{1}$ See further the Unifying Decision of the High Court, no. 9, dated 9.3.2006. 
i. the court before which it appears; ii. the full generalities of the plaintiff and the defendant, as well as their addresses;

iii. the concrete content of facts, circumstances, documents and evidence;

iv. filing allegations, rebuttals and arguments against the lawsuit;

v. electronic contact details of the respondent or his representative, if the respondent has any;

vi. the list of witnesses, specifying their exact addresses;

vii. the evidence required to be obtained from third parties or the plaintiff, specifying the reasons for obtaining it, as well as their location;

viii. the type of expertise required to be performed during the trial, if one is needed;

viii. the full generalities of the third persons required to be summoned to trial;

ix. counterclaim, if the respondent appreciates the exercise of this right 1 .

The submission of the statement of defence by the defendant is one of the most important moments for process development against him, as the civil procedural law has explicitly provided that the defendant cannot present objections and new evidence during the trial related to the lawsuit, if he has not presented them in the statement of defence. This means that for the allegations that the plaintiff has presented in the lawsuit and for the evidence that accompanies the lawsuit, the defendant by presenting his rebuttals and evidence in the statement of defence and is not allowed to present them later in the trial.

1 Point 3 and 4 of the article 158 of the Code of Civil Procedure, amended by law no. 38/2017, provide:

"3. The "Statement of Defense". is drafted in the Albanian language and must contain:

a) the court before which the statement of defense is submitted;

b) the name, paternity, surname, place of residence or domicile of the plaintiff, the defendant and the persons respectively representing them, if any. If the plaintiff or the defendant is a legal entity, its name as it appears in the public registers, indicating the headquarters or head office, where the notification will be made.

c) the concrete statement of facts, circumstances, documents and other evidence, as well as the objections and arguments for opposing the lawsuit, if any.

4. In addition to these requirements, the respondent shall state clearly in / or attached to the statement of defense:

a) his electronic contact details or his representatives, if any, which the court may use to notify him;

b) the list of persons who request to be summoned to trial as witnesses, specifying exactly their names, paternity, surname and full address, as well as the facts that he seeks to prove with them;

c) the evidence should be taken to third parties or to the applicant, specifying the reasons and the location of evidence;

c) the type of expertise required to be performed during the tria;

d) counterclaim, when he is required to exercise this right under Article 160 of this Code". 
Another element of the principle of adversarial proceedings has to do with the fact that each of the parties during the examination of the case has the right to actively participate in the judicial process, in the judicial investigation of the case. This means that each of the parties has the right to make a debate and litigation, for any evidence presented by making legal submissions, regarding the value and evaluation of evidence, expressing legal opinions on the facts and circumstances proven at trial.

The application of this principle by the court is a basic condition for the development of a regular civil litigation, as this principle is the basis on which a civil litigation is based, it is the essence of any civil litigation. There is no regular civil litigation without the application of this principle. This principle includes the obligation of the court to enable the party to be heard before the trial, and at any level of the civil litigation, with the legitimacy of the parties in the process and their explanations about the object of the lawsuit, with the judicial investigation until in the final discussion of the parties.

Another element of this principle is that it applies at every stage of the trial, that is, every party must be given the opportunity to oppose by presenting its claims and relevant evidence at every stage of the trial. Particularly important is the application of this principle in the judicial investigation phase, which is the phase where the parties should present the evidence and the facts on which they base their allegations, and adversarial means that any evidence is subject to litigation by the parties and each party must give his arguments for the evidence he presents, as well as for the evidence presented by the opposing party.

The law stipulates that it is the duty of the court to seek the application of the principle of adversarial proceedings at every stage of the main trial. This task of the court is defined, explicitly in the Code of Civil Procedure, according to which the court is obliged to apply, at every stage of the process, the principle of adversarial proceedings. For this purpose, the court also orders the performance of various actions or the submission of acts, and documents, by the parties in the process in favour of each other. Such a thing should be done in order for a party to have the opportunity to be defended, as well as to correctly apply the principle of adversarial proceedings, and this princile should be acquainted with the acts, evidence and documents of the other party, so she effectively carry out her defense. Obligations arise for the correct application of the adversarial principle, not only for the court, which must follow and seek the application of this principle, but also for the parties. This also results from the civil procedural law, which in application of the principle of adversarial proceedings, charges the parties with the obligation to inform each other within a certain time, with the facts and evidence, where, they base their claims. ${ }^{1}$

\footnotetext{
${ }^{1}$ Article 19 of the Code of Civil Procedure stipulates: "The parties must inform each other, in a timely manner, the means and facts on which they base their claims, the evidence they will present and the legal provisions to which they will refer, in order to enable each party defending their interests at trial".
} 
According to the civil procedural law, each litigant must, within a certain time, inform the other party about the means and facts, where it bases its claims, the legal basis of the research, as well as the concrete evidence, where bases its claims. Informing the other party, with the nature of the allegations, with the means and facts, where it bases its claims, as well as with the legal basis of the allegations, is made by the plaintiff by submitting to the defendant a copy of the lawsuit are presented, in summary, the means and facts on which the plaintiff bases his claims, as well as the legal provisions on which he bases these allegations.

The same must be done according to the law by the defendant, who must notify the plaintiff within a certain time of all the means and facts, on which he bases his objections, of all the evidence he will present, as well as of the legal basis, where he refers to his objections, in order to enable the plaintiff to realize the protection of his interests in the trial. Mutual acquaintance of the parties within a specified period of time with the means, facts, evidence on which they base their claims, as well as with the legal basis on which the parties refer their claims, is necessary in order for the parties to defend their interests in trial, as well as to apply the principle of adversarial proceedings in a fair and correct manner. Without prior knowledge of the means, facts, evidence and legal basis on which each party bases its claims, the other party may not submit its means, facts, and evidence, so to that party is not given the effective opportunity to debate any claim of the other party, by not applying in practice, the principle of adversarial proceedings.

An important element of the adversarial principle deals with the fact that when the decision for a party is given in his absence, the law recognizes this party the right to appeal this decision in the higher court. Such a thing is provided in the Code of Civil Procedure, which stipulates that in cases when the law allows the decision for one of the parties to be given in his absence, he has the right to appeal to the highest court, against the above decision.. ${ }^{1}$

As noted, this provision provides for an exception to the general rule set out in Article 18 of the Code of Civil Procedure, according to which no party may be tried without being heard, or without being summoned to trial. In this case, the law provides as an exception that a party can be tried without being heard or even without being called to trial, but for this, two conditions must be met at the same time:

First: The law should explicitly provide that the trial may take place without notifying the other party;

Second: This judgment must be necessary in the circumstances of the case.

\footnotetext{
${ }^{1}$ Article 21 of the Code of Civil Procedure stipulates: "When the law allows it and the circumstances of the case require a court decision, regardless of the knowledge of one party, the latter has the right to appeal in court against the decision".
} 
In cases when the law provides that the trial against a party be conducted even without notifying this party, we can mention the cases provided by Article 202 et seq. Of the Code of Civil Procedure, which determine the security of the lawsuit. Specifically, Article 205/2 of this Code provides that: "2. The request (meaning for securing the lawsuit) is examined in the presence of the parties, but in special or urgent cases, it can be examined in the deliberation room". This provision which provides for the civil trial for securing the lawsuit, without notifying the other party, in its very content, provides that the trial without notifying the other party, is an exception, as as a general rule, is done by notifying the other party and this exception occurs only in special or urgent cases, in those cases when the nature of the matter cannot be notified to the other party, because the delay (which is the time required to notify the other party) may cause serious and irreparable harm to the other party.

With the fulfillment of these two conditions, the trial of securing the lawsuit can take place even without hearing the other party, however, the law in order to protect the interests of the party, who was not heard in that trial, as well as to apply the principle of adversarial proceedings, has provided in Article 21 of the Code of Civil Procedure the right of this party to appeal against the decision given. The realization of the appeal by this party, gives the possibility for the case to be tried by another court, higher, since both parties are present, the principle of adversarial application is applied. This provision recognizes, in this way, the party which has been tried in absentia, not through its own fault, to have the opportunity to realize the protection of its interests in the trial in another instance of the judicial system. At this stage, this party has all the possibilities to apply the principle of adversarial proceedings, to present its claims and evidence and thus to realize the constitutional and legal principle according to which, everyone has the right to be heard before being judged.

The application of the principle of adversarial proceedings in any civil litigation has a great legal significance and we can say that this principle constitutes a "sine qua non" condition, i.e a condition without which there can be no fair civil litigation. Based on and in application of this principle, the court decides on the resolution of the dispute between the parties and the court is obliged to base its decision only on the facts and evidence presented by the parties, where they have been able to debate, according to the principle of adversarial proceedings. Such a thing results, explicitly from the content of Article 20/2 of the Code of Civil Procedure which stipulates: "It (meaning the Court) bases its decision only on the means, explanations, documents and other evidence indicated or brought by the parties, when the latter have been able to debate according to the principle of adversarial proceedings". 
Regarding the importance of the principle of adversarial proceedings, as one of the basic principles of the civil process, even the Constitutional Court of the Republic of Albania has expressed itself continuously. Thus, in its decision, no. 69, of 2000, this Court, inter alia, has reasoned: "...The principle of adversarial proceedings, as one of the most important principles that should characterize the judicial process in the sense of Articles 18, 19, and 20 of the Code of Civil Procedure, is related to the right of the litigants to be heard, to inform each other within a certain time with the means and facts on which they base all their claims, the evidences, the correct legal reference, in order to realize as fairly as possible for the protection of their interests in the trial....".1

In another decision of the Constitutional Court of Albania, specifically in decision no. 34, of 2011, in relation to this principle, this Court, inter alia, states that: "... The Court, in its jurisprudence, has made part of the standards for a regular legal process the observance of the principle of contradiction, although not explicitly expressed in constitutional norms. In view of the above, the principle of adversarial proceedings, seen from the point of view of equality of arms in civil proceedings, is a logical evolution of the right of a party to participate in the trial and to be treated fairly and equal by a fair and impartial judge (arbitrator) who guarantees both parties the same opportunities to disclose their evidence and arguments. If there were no equality of arms in the civil trial, then the arguments of one party would prevail over the arguments of the aggrieved party and, consequently, the right to participate in the trial would be stripped of its constitutional function, to guarantee a fair legal process. ..."2.

In view of the above, since there is a constant and consolidated jurisprudence of the Court on the principle of equality of arms, it can no longer be doubted that this principle is already a constitutional guarantee which appears as an integral part of the guarantee for a regular legal process.

The importance of the principle of adversarial proceedings should also be seen as part of international law, which includes international acts guaranteeing fundamental human rights and freedoms. Of these international acts, an important place is occupied by the European Convention on Human Rights, which in its article 6, point 1 guarantees the right to a fair legal process, even in the adjudication of civil disputes, as well as in the trial of criminal charges against the person.

As the Strasbourg Court has emphasized in some of its decisions, the application by the Court of the principle of adversarial proceedings in civil proceedings is one of the most important elements of the civil judicial process, and its non-enforcement has serious and irreparable consequences for the process, violating the right of the person to a fair legal process. According to the practice of this Court, this principle consists of several elements, among the most important are:

\footnotetext{
${ }^{1}$ See also: the decision of the Constitutional Court, no. 69, dated 16.10. 2000, published in the Official Gazette, no. 33/2000.

2 See also: Decision no. 34, of 2011, of the Constitutional Court of the Republic of Albania.
} 
- the right of a party to be summoned to trial and to be heard at the Court;

- the right to be acquainted with the allegations and evidence of the other party;

- the right to debate and to oppose the evidence of the opposing party;

- the right to present any necessary evidence, as well as contradictions and objections in relation to the lawsuit filed;

- the right to have the necessary time to carry out the defense and to present the relevant allegations and evidence;

- the right to be treated impartially and equally by the Court, in relation to the other party, etc.

Specifically, the Strasbourg Court in case no. 35289/11 ECHR, Renger vs. The Czech Republic, in paragraph 146 of the Decision of 31 August 2018, on the principle of adversarial proceedings, states, inter alia, that: "... In the civil process, adversarial proceedings are closely linked to the equality of arms in the process, where each party must be given the necessary time and opportunity to present its claims and evidence, as well as to oppoose the arguments and evidence of the other party, as part of a fair legal process"....".

In another of its decisions, dated March 8, 2010, in the case Caka v. Albania, for this important principle of civil proceedings, this Court, among other things, determines that: "...In any process the court is obliged to apply the principle of adversarial proceedings as part of legal process, recognizing the parties the opportunity to have the necessary time to prepare the defense, to present their claims and rebuttals, as well as to object to the arguments and evidence presented by the other party....2".

\section{Conclusion}

At the end of this paper we can draw some conclusions about the matter addressed in this article, where the first conclusion is that the adversarial proceedings principle is one of the basic principles of the civil process. This means that there will be no fair civil litigation if the court does not apply correctly this principle and the violation of this principle constitutes a violation of a fair legal process.

\footnotetext{
${ }^{1}$ See further: The decision of the Strasbourg Court of 31 August 2018, in case no. 35289/11 ECHR, "Renger v. Czech Republic.

2 See also: The decision of the Strasbourg Court of 8 March 2010, in the case of Caka v. Albania.
} 
Another conclusion that can be drawn from this paper is that the adversarial principle is applied by the court not only during the proceedings of the main trial, but also before the start of the trial. According to the civil procedural law, the court is obliged that after the defendant has submitted the lawsuit and the relevant evidence, to send them to the plaintiff, giving them the necessary time to present his objections and the evidence he intends to present in trial. This is provided by the legislator in order to conduct the civil litigation as soon as possible and within a reasonable time, which in turn constitutes of a special element of a fair legal process.

Another conclusion that can be drawn from this paper is that seen from a historical point of view, there are two systems of civil process that we know; the investigative process and the adversarial one. In the investigative system the role of the parties is passive, and the court has an active role that collects evidence and orientates the parties, while in the adversarial system the court has a passive role and it is the parties who present all the evidence and the court bases its decision only on evidence presented by the parties.

One of the most important elements of the adversarial principle is the right of a party to be summoned to trial and to be heard in court. The right of a party to participate in the trial is not absolute, this right does not benefit the party hiding from justice. This element constitutes the initial and elementary right of this principle, and if the party is tried without a hearing, the principle of adversarial proceedings will be impossible to be applied due to the absence of the opposing party and such an approach held by the court constitutes a violation of the right to a fair legal process.

The principle of adversarial proceedings is at the core of the entire civil litigation. Pursuant to this principle, the parties have the right to present claims and rebuttals, to present evidence and facts on which they base their claims, to debate and challenge the evidence and claims of the opposing party, to offer their legal opinions on the resolution of the case by the court, as well as to enable the implementation of the principle of equality of equipment in the process. This principle is not only legal but also constitutional, as the Constitution of Albania itself provides for the right of a party to be heard before being tried. Also, this principle is an important part of the process of order of law provided by the Constitution of Albania and the European Convention on Human Rights, sanctioned in several decisions of the Constitutional Court of Albania and the Strasbourg Court.

\section{References}

[1] The Constitution of the Republic of Albania;

[2] Code of Civil Procedure of the Republic of Albania;

[3] Civil Code of the Republic of Albania;

[4] Kola, Tafaj, F; Vokshi; "Civil Procedure", Part II, Edition II, printed by the Publishing

[5] House "Albas", Tirana 2018; 
[6] Lamani, Alqiviadh, "Civil Procedure", Tirana: 1961, page 24

[7] Unifying Decision of the High Court of the Republic of Albania, No. 9, dated 9.3.2006.

[8] Decision of the Constitutional Court of the Republic of Albania, No. 69, dated 16. 10. 2000, published in the Official Journal, no. 33/2000.

[9] Decision no. 34, of 2011, of the Constitutional Court of the Republic of Albania;

[10] Decision of the Strasbourg Court dated 31 August 2018, in case no. 35289/11 ECHR, "Renger v. Czech Republic";

[11] Decision of the Strasbourg Court dated 8 March 2010, in the case of Caka v. Albania. 